\title{
The importance of considering African indigenous languages in the decolonisation of legal education and practice
}

\author{
Keneilwe Radebe - University of Pretoria \\ Charles Maimela - University of Pretoria
}

Journal of Decolonising Disciplines

Volume 2, Issue 1 (2020)

eISSN: 2664-3405

DOI: https://doi.org/10.35293/jdd.v2i1.39

\section{Abstract}

The issue of promoting indigenous languages is a very contentious and crucial issue, which also came to the fore during the Fees Must Fall Movement wherein academics were accused of being intellectually colonised, among other things. Language and culture are intimately connected, which means that one cannot understand culture without having direct access to its language. Learning a language can be equivalent to learning a particular society's behaviour, culture and custom. Therefore, it should be emphasised that language is culture and culture is language. The question arises: how can African indigenous law or African customary law be promoted within the law curriculum when South African indigenous languages are marginalised? For instance, student leaders during the Fess Must Fall protests echoed that academics are intellectually colonised; they are academic thugs (Makalela 2018: 1). Thus the Fees Must Fall movement, as articulated by Makalela (2018: 2), presents a continuation of an age-old struggle, but with more focus on the negative effects of corporate African universities, while also raising issues around culture and language that are not explicitly stated and addressed. This article reflects on the current situation with regard to teaching African customary law and argues that the subject remains marginalised. The immediate impact of this state of affairs is that a form of injustice take place when litigants affected by African customary law appear before courts. This situation as emphasised in this article emanates from the fact that South African indigenous languages are marginalised, thus resulting in the ultimate marginalisation of indigenous cultures. The central argument of this article is that in the absence of a commitment to promote South African indigenous languages, African customary law as an academic subject and in legal practice will not be fully beneficial to African indigenous people and South Africa as a country.

Keywords: African customary law, indigenous languages, African people, law curriculum, legal practice 


\section{Introduction}

African customary law is a legal system that is recognised in South Africa and forms part of the law of the indigenous people of South Africa. Due to colonialism and apartheid, this legal system was rejected and under-developed, and common law was favoured against it. The supremacy of the postapartheid Constitution and the recognition of African customary law as a legal system independent of the common law, aimed to correct and reconcile the past injustices due to the under-development of this important legal system. As to whether the Constitution and higher learning institutions have attained the goal of developing African customary law in South Africa is a question that will be explored and debated in this paper. The aim of this contribution is to assess the role of universities in developing African customary law through their teaching, as well as to outline how the relegation of South African indigenous languages affects the development of African customary law in universities and in general. Furthermore, reference will be made to legal practice, specifically in South African courts. Thereby, an argument is made that the marginalisation of South African indigenous languages constitutes a barrier to justice and a miscarriage of justice. Possible solutions will be discussed in the paper with the aim to ensure that African customary law is developed as an academic subject, and to contribute to the debate that is currently preoccupying universities and various stakeholders in higher learning. Curriculum decolonisation, which is key to the future development and inclusiveness of the South African community that is so diverse, will be addressed in the contribution as a possible solution.

\section{Background and meaning of African customary law}

Most South African universities prescribe a course in customary law as a prerequisite to comply with the requirements for a degree in law. Section 211 of the Constitution gives recognition to customary law as an independent legal system, which was not the case in the past (Section 211 (3) of the Constitution of 1996). There are also other legal systems of a religious nature which are observed in South Africa, but are not as yet recognised, such as those of the Muslim and Hindu religions (Rautenbach 2018: 62 ). When a matter unavoidably deals with these systems of law, they may be applied subject to the Bill of Rights as enshrined in the Constitution. The application of these systems of law and customary law is mostly in the field of private law, especially family 
law. This is the case because South Africa is a multicultural society, and diversity is the order of the day (Maithufi 1996: 298).

South African universities teach customary law as recognised by the Constitution. However, universities employ different names to describe this subject or course. Some universities, such as the University of South Africa, call it African Customary Law, while the University of KwaZulu-Natal calls it Legal Diversity. Other universities like the University of Pretoria use the term Legal Pluralism. Legal Pluralism is used to indicate the plurality of legal systems that are observed in South Africa. Despite the title of the subject, most universities indicate in their study materials or course outlines that the subject deals with the study of customary law. Customary law has been defined as the customs and usages observed among the indigenous African peoples of South Africa, and which form part of the culture of those peoples (S1 of the Recognition of Customary Marriages of Act 120 of 1998). Another term used to describe this legal system is Indigenous law, which means that it is the law of the indigenous people of South Africa and their way of life. It is not the aim of this contribution to outline which is the correct description employed by universities when it comes to African customary law; but what is fundamental in this case is that this legal system owes its origin to the indigenous people of South Africa and must be preserved.

\section{Teaching African customary law in universities}

The majority of South African law students study a course in customary law for a period of about four to five months. They, however, have to study other law courses for longer than this period. These courses deal with principles of common law in private and public law. South African law students study the South African common law for a period of approximately four to five years, while a course in customary law is offered for a limited period as indicated above. This situation creates the impression on the part of both students and lecturers that customary law is not a major component of South African law, despite the fact that it is a recognised legal system (albeit one that is still under-developed after 25 years of the democratic dispensation).

The use of African legal concepts which may not have been properly explained in textbooks, usually leads to dissatisfaction on the part of students and lecturers alike. This is because customary law textbooks are written only in English and Afrikaans. 
The cumulative effect of this state of affairs is that

the sometimes expressed, but more often implicitly communicated view of most law teachers [is] that African customary law is not very important or does not really exist. By never or seldom referring to African customary law and by the tone of voice when African customary law is referred to, the students' view of the relative importance of the general law and customary law can only be reinforced. (Visser 1990: 68)

The use of vernacular language in explaining concepts in customary law may be useful to those who understand such languages. In the case of those not familiar with that language, that is both students and lecturers, such code-switching may cause confusion in understanding the legal concept that is explained. It is, however, surprising that most South African law students are capable of grasping the meaning of the Latin terminology that is regularly used in explaining legal concepts in the common law, yet fail to comprehend the meaning of the terminology used in explaining concepts in customary law, which is rather unfortunate in the 'new' South Africa. This affirms that students and lecturers who are not speaking any of the nine indigenous languages recognised in South Africa can learn them to have a better understanding of customary law. As much as African people can speak English and Afrikaans as was historically imposed on them, it is not unfair to require students to learn indigenous languages with the aim of ensuring that they have a better understanding of customary law and, in turn, customary law can begin to be codified in indigenous languages. The distortion of customary law emanates from the fact that it is written in foreign languages, which in most instances cannot be translated to any of the indigenous languages, as will be outlined below. African customary law concepts or principles like Ubuntu among others are significant because they encourage social cohesion and nation building, which is fundamental in a democratic South Africa (S v Makwanyane 1995 (6) BCLR 665).

While South African universities prescribe relatively brief courses in customary law, other universities have decided not to offer customary law as an independent subject and rather teach it in conjunction with other courses or subjects dealing with the common law. For example, customary law relating to marriage may be taught together with common law marriages, or customary laws of succession with those of the common law, etc. The problem with this approach is that most textbooks used 
in discussing all branches of common law do not adequately address the provisions of customary law, the conflicts that may arise from the application of these systems of law, as well as possible solutions to these conflicts. Furthermore, this approach of co-teaching customary law with common law results in customary law being swallowed up by the common law content, and this does not contribute towards the transformation of the LLB curriculum, contrary to the arguments of some law schools in South Africa ( Nhlapo 2017: 17).

As a result of the limited time set aside for the study of customary law, dissatisfaction may reign supreme among lecturers and students. All are pressed for time to write and prepare for tests and examinations during this limited period of teaching and learning customary law. Again, the problem relating to the medium of instruction raises its ugly head for those students who may not be conversant with customary legal concepts and those not familiar with the language of instruction. Immediately before the examination in the module of customary law, the lecturer is expected to provide students with a scope for the examination, which may amount to actually disclosing the contents of the paper, and this is unfortunately the practice in most if not all South African universities. The reason is that pass rates are made a priority at the expense of quality: because customary law is taught and written in English, a compromise is reached as indicated above, resulting in adverse consequences for legal practice in the area of African customary law (Visser 1990: 52).Students do not struggle with the module, however the standard of the module is compromised for example through the failure to explain customary law terms and culture in indigenous languages and this ultimately results in poorly trained lawyers in the field of customary law.

Lamenting about the time devoted to the teaching of customary law and the attitudes inculcated thereby, Visser (1990: 69) has this to say:

Just think of how the simple fact of time devoted to the teaching of law, other than African customary law, in the typical South African curriculum must convince a student that the general law is more 'important' than African customary law. Generally, it takes a student four to five years to attain the LLB degree. During this time, he or she is required to do four or five courses in private law, one or two courses in commercial law and at least one course in Roman law, criminal law, criminal procedure, civil procedure, and conflict of laws..., interpretation of statute, administrative law and jurisprudence. All 
these courses add to the Eurocentric nature of the general law.

This limitation has resulted in students not being sufficiently equipped to tackle cases in the area of customary law. Furthermore, the relatively limited role and importance of customary law in the legal fraternity is emphasised through a high number of court cases dealing with customary marriages, inheritance and succession among others. This is made clear when the Judicial Services Commission, as the regulatory and appointing body of judges, interviews candidates for the position of judge. In most instances, candidates appear to be weak in this area of the law and universities must heed the call in addressing this shortcoming when it comes to teaching African customary law. Legal training should equip candidates with relevant knowledge and skills while at the same time fulfilling the constitutional obligation of developing African customary law in South Africa.

\section{Language as a major hurdle in teaching African customary law}

For a very long time, English and Afrikaans were the only two official languages recognised in South Africa. Tuition in South African universities was and still is conducted in the medium of these two languages. This is despite the current efforts in curriculum transformation to eradicate Afrikaans as a medium of instruction and to advance English as the single medium of instruction in South African universities. It was only after the adoption of the Constitution of 1996 that the other South African indigenous languages were made official languages (Sections 30 and 31 of the Constitution). In practice, however, South African universities use none of them as a medium of instruction. Consequently, South African universities were grouped into the following categories with regard to their use of medium of instruction: Those that offer tuition in Afrikaans only; those that offer tuition in English only; and those that offer tuition in both English and Afrikaans.

Despite the fact that eleven official languages (Sepedi, Sesotho, Setswana, Siswati, Tshivenda, Xitsonga, Afrikaans, English, isiNdebele, isiXhosa and isiZulu) are recognised by the Constitution, the medium of instruction in South African universities has remained English and Afrikaans, 25 years into the democratic dispensation. This undermines the right of African people to be taught in their mother tongue or language. All textbooks in the subject of customary law are written exclusively in English and Afrikaans. It is clear that prospective and university 
students must be conversant in English or Afrikaans to succeed in university studies. Considering the background from which the majority of the prospective and current South African students are drawn, it will require time and considerable effort on the part of educational authorities to ensure that students have a thorough knowledge of these languages.

All textbooks in customary law use certain expressions, which are derived from indigenous languages that are not languages of instruction, to explain legal principles which cannot easily be translated into one of the two major languages of instruction. Examples from the field of family law will suffice to indicate this. Words such as lobolo (bohali, bogadi, mogadi), ukuthwala, ukungena, phuthuma, seantlo and others are frequently used by authors in customary law (Bekker 1995; Bennett 1995; Himonga \& Nhlapo 2014). This aspect is illustrated in the latter part of this article wherein it is demonstrated on how the misinterpretation of customary law terms and concepts has in some cases resulted in injustice to parties before a court of law. The implication is that lecturers in this field should be sufficiently knowledgeable with the expressions from these languages so that they may correctly describe these concepts for the benefit of students. Learners in South Africa tend throughout their schooling years to be taught in English or Afrikaans, some without studying even the basics of the indigenous language that may be their mother tongue. Although there is an option to learn indigenous languages until Matric English remains the language of primary medium in instruction and this had resulted in indigenous languages not being developed as languages suitable for scientific study.

The problems associated with the use of English or Afrikaans to describe customary law concepts have been described as follows by Rautenbach (2018: 25):

The effort to express African concepts in English or Afrikaans may give rise to misunderstanding. Bennett discusses at length the misconceptions arising from calling customary land tenure communal. It is thus paramount to always keep in mind that a misconception regarding the true content of a customarylaw rule could exist as a result of a difference between the language in which it is practised and that which is written down.

Teaching customary law in indigenous languages is a priority in South Africa, with the aim of ensuring that students are taught proper customary law and not the distorted version. The true meaning and understanding of customary law is lost 
through translations. Although customary law is not monolithic various similarities in their performance of rituals exist between various indigenous groups. As part of decolonising legal education, courses like African customary law must be taught in indigenous languages with the aim of developing this legal system and at the same time developing indigenous languages and culture. It is important to note that understanding customary law not only as a legal system but also a belief and a way of life for African people of South Africa is something that must not be taken for granted. At this point it is clear that the development and understanding of African customary law lies in language.

\section{Language and access to justice in South African courts}

The relegation of African culture and the African philosophy emanates from colonialism. As Mudimbe (1988: 5) notes, 'The fact of the matter is that until now, Western interpreters as well as African analysts have been using categories and conceptual systems, which depend on a Western epistemological order'. In this state of affairs, philosophy or laws are characterised as a less sophisticated system of law and are therefore neglected. Mamdani, for instance, makes a distinction between the two populations through which the colonial state constituted itself, namely: races and ethnicities. He mentions that races were governed through civil law whilst customary laws governed ethnicities (Mamdani 2005: 5). Those governed by civil law were considered as sophisticated whilst those governed my customary laws were considered less sophisticated or were not considered as members of civilised society.

According to Ngũgĩ, language can be used as a form of spiritual subjugation (Ngũgĩ 1986:9). He mentions the following: 'In my view language was the most important vehicle through which that power fascinated and held the soul prisoner. The bullet was the means of the physical subjugation. Language was the means of the spiritual subjugation'. This power refers to the colonial imposition of a foreign language on indigenous people, which was central to the colonial agenda; its important area of domination was the mental universe of the colonised (Ngũgĩ 1986: 16):

Colonialism imposed its control of the social production of wealth through military conquest and subsequent political dictatorship. But its most important area of domination was the mental universe of the colonised, the control, through culture, of how people perceived themselves and their relationship to the world. 
The effect of the domination of English and Afrikaans is also transparent in South African courts. Harms (2012: 23) mentions that he does 'not know of any university South of Sahara that teaches law in a local language. Court language, at least in higher courts, is invariably European'.

Unfortunately, currently persons exclusively speaking indigenous languages are at a disadvantaged position in South African courts. Thus, in the absence of a very competent court interpreter there is a great risk of injustice (Hlophe 2004: 43). The current state of affairs is that English and Afrikaans are the dominant court languages and now English has recently been declared the only official language of record (Mogoeng 2017). It is also a pertinent fact that language plays a central role in allowing a person access to justice (Alberts \& Mollema 2013: 30). However, the fact that language also carries culture with it means a court interpreter also becomes a culture broker who translates, apart from words, ideas, laws and customs ( Hlophe 2004: 46). It should also be emphasised that language and culture appear in the same constitutional provision wherein the use of a language is linked to one's right to participate in culture; this appears in Section 30 of the Constitution of the Republic of South Africa, which provides the following: 'Everyone has the right to use the language and to participate in the cultural life of their choice, but no one exercising of these rights may do so in a manner inconsistent with any provision of the Bill of Rights'. Ngũgĩ (1986:16) again highlights the importance of language by asserting that

Language carries culture, and culture carries, particularly through orature and literature, the entire body of values by which we come to perceive ourselves and our place in the world. How people perceive themselves affects how they look at their culture, at their politics and at the social production of wealth, at their entire relationship to nature and other human beings. Language is thus inseparable from ourselves as a community of human beings with a specific form and character, a specific history, a specific relationship to the world.

It is thus of utmost importance for interpreters to take full cognisance of issues of culture when interpreting for people who speak different indigenous languages (Lebese 2015: 69). This is because 'language is embedded in culture and unless one understands the cultural aspects of a particular language there is a risk of miscommunication' (Lebese 2015: 70). 
The relegation of indigenous languages in courts has ultimately resulted in the marginalisation or subordination of African customary law or African culture. This is because the dominance of European languages in courts has prevented the development of a modern scientific legal vocabulary in respect of African languages (Harms 2012: 23). Situations arise when there have been misrepresentations of facts in an African context resulting in a form of injustice. Alberts and Mollema make reference to a situation where an accused was wrongly acquitted as a result of a misinterpretation. Their illustration follows (Alberts \& Mollema 2013:44):

Sebatakgomo (English: a cry for help) by a plaintiff (a woman who was raped) was misinterpreted by a Sesotho court interpreter as 'Ke batla kgomo' ( English: 'I want an ox') and as a result the perpetrator (rapist) was set free. In another case, an accused was wrongfully acquitted based on the erroneous interpretation of an African term literally meaning 'arrow', but 'gun' in the context of the trial.

Another example emanates from Kaschula and Mostert (2008: 95), wherein the authors sought to portray cultural misunderstanding in court as follows:

Interpreter:Uyakuvuma ukuthi ubulele ingane? ( 'Do you admit that you killed a baby?')

Accused: Ngibulele uTikoloshe! ('I killed a Tikoloshe!')

Interpreter: He says yes, My Lord.

Judge: He said a good deal more than that, what exactly did he say?

Interpreter: My Lord, he says he killed a Tikoloshe

Lawyer: An evil spirit.

Compounding the potential for such misunderstanding are Latin concepts such as amicus curiae, bona fide, caveat, de facto, erratum and obiter dictum, which are known and understood by a majority if not all law graduates and legal practitioners, but may seldom be encountered by the general public of South Africa. It is unfortunate that attorneys, advocates, judges and magistrates are required to prioritise Latin ahead of indigenous legal concepts in the course of an LLB degree (Malonde 2018: 12).

The above examples of court misinterpretations also go hand in hand with the nature of African customary law, which is context-based. Language should therefore be interpreted in light of the applicable cultural context. For instance, commentators such as Himonga and Dialo (2017: 11) mention that African custom cannot be 
abstracted from social contexts, because they

are embedded in the social realities within which people live their lives. In addition, the values of certainty, stability and predictability - which are core to western legal cultures - are not necessarily the primary goals of dispute resolution in living customary law.

In another example, an accused was under the impression that a confession in legal terms has a similar implication to a confession made before a priest, which is forgiveness (Hlophe 2004: 46). This example demonstrates that culture and language issues cannot be separated. Thus, the continued marginalisation of South African indigenous languages has the eventual effect of stalling the effective development of African jurisprudence (Hlophe 2004: 43). As mentioned above, the LLB degree does not promote African indigenous languages and this emanates from the fact that it is Eurocentric. One of the best ways of avoiding future distortions and misinterpretations of African concepts and African worldviews is by solving African challenges through using or applying indigenous languages (Fayemi 2013: 4). Fayemi, argues that Western linguistic categories will not assist in defining what African philosophy is and how customary law can be developed as provided for by the Constitution (Fayemi 2013:6).

Ralarala also mentions that our South African courts, and particularly the criminal justice system, are still confronted by linguistic and cultural challenges (Ralarala 2012: 56):

The actual translation of a police-sworn statement as a reconstruction of the complainant's oral narrative has serious, far-reaching implications when such translation involves witnesses that come from different cultural and linguistic backgrounds, not only for the complainant and the perpetrator but also for law enforcement personnel or police officers (hereafter referred to as transpreters) who might find it difficult to gather evidence as a result of language barriers.

Importantly, Ralarala(2012: 55) claims that central to the above interpretation challenge is the potential for injustices. Ralarala further argued that law is made possible by language and furthermore, that language reflects society. The relegation of African indigenous languages in courts is particularly worrisome since a large 
majority of South Africans speaks African indigenous languages and as a result, their culture remains marginalised. Ralarala (2012: 60) reaches the conclusion that

Further complicating the issue is the fact that speakers of African languages hail from a rich cultural background and heritage, and as such, this human peculiarity involves a somewhat unique structure of thinking and a variety of communication patterns that are influenced by particular speech acts, which are different from the native speakers of other languages such as English and Afrikaans.

Unfortunately, practical and economic reasons have been cited for the inability of affording equal status to all eleven official languages in South African courts (Hlophe 2000: 696). However, Hlophe (2000: 694) argues that such 'practical' considerations are for the convenience of presiding officers. For Hlophe, this argument is based on an apartheid legacy, as most presiding officers were only conversant in English and Afrikaans (2000: 695). He also questions the absence of judgments written in indigenous South African languages despite the fact that the Constitution provides for the equality of the eleven official languages. The writing of judgments in indigenous South African languages would at least be a step towards enforcing or promoting Section 6 (2) of the South African Constitution which enjoins the state to take practical and positive measures to elevate the status and advance the use of indigenous languages in our country. Hlophe (2000: 694) argues that the constitutional provision pertaining to the equality of the eleven official languages is not given effect. This demonstrates how the South African Constitution and government are unable to give effect to the promotion of indigenous languages. The above state of affairs emanates from the fact that African indigenous languages and culture are not promoted and enhanced as part of the LLB programme. The negative effect of the failure to promote African indigenous languages and culture in the LLB curriculum is reflected by Kaschula and Mostert (2008: 91) in their remark that

We all know that no legal system will ever succeed in establishing itself as a social system efficiently if it is not founded on the fundamental cultural rhythms of the majority of the population in its borders. Yet we continue to teach young indigenous Africans how to be good Roman, Dutch, and English law specialists. They are becoming foreigners in their own land. 
Future generations will not know and understand customary law and this in turn will affect the cultural life of indigenous communities. The state and higher learning institutions must prevent this from taking place.

\section{Conclusion}

The essence of this article is that language is a carrier of people's culture. African customary law can therefore be beneficial to African people and South Africa more generally only if it speaks their language and speaks to their culture. In this way, indigenous people's dignity will be restored and the risk of legal misrepresentations, which could result in an injustice against African litigants, will be alleviated. South African universities must also heed the call of ensuring that they produce Africancentred graduates. Offering African customary law in one of the indigenous languages will be a start and a contributor towards the curricular transformation debate that is ongoing in South African universities and society. The challenge regarding the promotion of indigenous languages outlines the fact that language rights and cultural rights presents a very emotive issue and are of considerable importance for the future growth of South Africa. 


\section{References}

Alberts, M. \& Mollema, N. (2013). Developing legal terminology in African languages as aid to the court interpreter: A South African perspective. Lexikos 23: 29-58.

Bekker, J.C. (1989). Seymour's Customary Law in Southern Africa. Cape Town: Juta.

Bennett, T.W. (1995). Human Rights and African Customary Law under the South African Constitution. Western Cape: Juta.

Fayemi, A.K. (2013). The problem of language in contemporary African philosophy: some comments. Inkanyiso, 1(5): 1-11.

Harms, L.T.C. (2012). Law and Language in a multicultural society. Potchefstroom Electronic Law Journal, 2(15): 21-31.

Himonga, C. \& Diallo, F. (2017). Decolonisation and teaching law in Africa with special reference to Living Customary Law. Potchefstroom Electronic Law Journal, 20: 1-19.

Maithufi IP, Mnisi Weeks S, Mofokeng L, \& Ndima D and (eds) Chuma H \& Nhlapo $\mathrm{T}$ (2014). African Customary Law in Southern Africa: Post-apartheid and Living Law perspectives. Cape Town: Oxford University Press.

Hlophe, J.M. (2000). Official languages and the courts. South African Law Journal, 117(4): 690-696.

Hlophe, J.M. (2004). Receiving justice in your own language: The need for effective court interpreting in our multilingual society. Advocate: 42-47.

Kaschula, R.H, Mostert \& Ralarala MK (2008). Communicating across cultures in South African law courts: Towards an information technology solution. Stellenbosch Papers in Linguistics PLUS, (36): 89-104.

Lebese, S.J. (2015). Formulation of court interpreting models: A South African perspective. Stellenbosch Papers in Linguistics, (44): 61-80.

Maithufi, I.P. (1996). Customary Law of marriage and the Bill of Rights in South Africa: Quo vadis?. THRHR, (2): 298-308.

Makalela, L.M. (2018). Our academics are intellectually colonised: Multi-languaging and Fees Must Fall. Southern African Linguistics and Applied Language Studies, (46):1-11.

Malonde, Z. (2018, 23 July). Use of African language in court system. Herald Live. https://www.heraldlive.co.za/news/2018-07-23-use-african-language-in-courtsystem/ 
Mamdani, M. (2005) Political identity, citizenship and ethnicity in post-colonial Africa. Keynote address to the World Bank. New Frontiers of Social Policy: 12-15 ( keynote address).

Mogoeng, M. (2017, 30 September). Mogoeng clarifies decision on English in court records. EyeWitness News. https://ewn.co.za/2017/09/30/mogoeng-clarifiesdecision-on-english-in-court-records

Mudimbe, V.Y. (1988). The invention of Africa. Bloomington: Indiana University Press.

Ngũgĩ wa Thiong'o. (1986). Decolonising the mind. Nairobi: Eastern African Educational Publishers.

Nhlapo T . (2017) . Customary law in post-apartheid South Africa: constitutional law confrontations in culture, gender and 'living law'. South African Journal on Human Rights (33) 1-24.

Ralarala, M.K. (2012). A compromise of rights, rights of language and rights to a language in Eugene Terreblanche's (ET) trial within a trial: Evidence lost in translation. Stellenbosch Papers in Linguistics, 41: 55-70

Rautenbach, C. (2018). Introduction to legal pluralism in South Africa. Durban: Lexis Nexis.

Republic of South Africa. The Constitution Act 108 of 1996.

Republic of South Africa. The Recognition of Customary Marriages Act 120 of 1998. S v Makwanyane (CCT3/94) [1995] ZACC 3; 1995 (6) BCLR 665; 1995 (3) SA 391; [1996] 2 CHRLD 164; 1995 (2) SACR 1 (6 June 1995) ( full case citation).

D P Visser 'The role of legal education in the internal conflict of laws' in A J G M Sanders (ed) The Internal Conflict of Laws in South Africa (1990) 67. 
